\title{
Treatment beyond progression with anti- PD-1/PD-L1 based regimens in advanced solid tumors: a systematic review
}

Francesco Spagnolo ${ }^{1 * \dagger} \mathbb{D}$, Andrea Boutros ${ }^{1 \dagger}$, Federica Cecchi ${ }^{1}$, Elena Croce ${ }^{1}$, Enrica Teresa Tanda ${ }^{1}$ and Paola Queirolo ${ }^{2}$

\begin{abstract}
Background: Treatment beyond progression with immunotherapy may be appropriate in selected patients based on the potential for late responses. The aim of this systematic review was to explore the impact of treatment beyond progression in patients receiving an anti-PD-1/PD-L1 based regimen for an advanced solid tumor.

Methods: A systematic literature search was performed to identify prospective clinical trials reporting data on overall response rate by immune-related criteria and/or the number of patients treated beyond conventional criteria-defined PD and/or the number of patients achieving a clinical benefit after an initial PD with regimens including an anti-PD-1/PD-L1 agent which received the FDA approval for the treatment of an advanced solid tumor.

Results: 254 (4.6\%) responses after an initial RECIST-defined progressive disease were observed among 5588 patients, based on 35 trials included in our analysis reporting this information. The overall rate of patients receiving treatment beyond progressive disease was 30.2\%, based on data on 5334 patients enrolled in 36 trials, and the rate of patients who achieved an unconventional response among those treated beyond progressive disease was 19.7\% (based on 25 trials for a total of 853 patients).

Conclusion: The results of our systematic review support the clinical relevance of unconventional responses to anti-PD-1/PD-L1-based regimens; however, most publications provided only partial information regarding immunerelated clinical activity, or did not provide any information at all, highlighting the need of a more comprehensive report of such data in trials investigating immunotherapy for the treatment of patients with advanced tumors.
\end{abstract}

Keywords: Melanoma, Immunotherapy, Immune-related response criteria, Treatment beyond progression, Anti-PD-1

\footnotetext{
* Correspondence: francesco.spagnolo@hsanmartino.it

${ }^{\dagger}$ Francesco Spagnolo and Andrea Boutros contributed equally to this work.

${ }^{1}$ Medical Oncology 2, IRCCS Ospedale Policlinico San Martino, Largo R. Benzi 10, 16132 Genoa, Italy

Full list of author information is available at the end of the article
}

(c) The Author(s). 2021 Open Access This article is licensed under a Creative Commons Attribution 4.0 International License, which permits use, sharing, adaptation, distribution and reproduction in any medium or format, as long as you give appropriate credit to the original author(s) and the source, provide a link to the Creative Commons licence, and indicate if changes were made. The images or other third party material in this article are included in the article's Creative Commons licence, unless indicated otherwise in a credit line to the material. If material is not included in the article's Creative Commons licence and your intended use is not permitted by statutory regulation or exceeds the permitted use, you will need to obtain permission directly from the copyright holder. To view a copy of this licence, visit http://creativecommons.org/licenses/by/4.0/ The Creative Commons Public Domain Dedication waiver (http://creativecommons.org/publicdomain/zero/1.0/) applies to the data made available in this article, unless otherwise stated in a credit line to the data. 


\section{Précis}

Immunotherapy treatment beyond progression (TBP) may be appropriate in selected patients due to the potential of late responses. In the studies included in our analysis, $30 \%$ of patients received TBP and the overall rate of late responses was $4.6 \%$.

\section{Background}

Patients with advanced solid tumors who are treated with immunotherapy may develop atypical patterns of response, which initially meet conventional response criteria for progressive disease (PD) but later result in tumor regression or prolonged disease stabilization (SD) $[1,2]$. To evaluate the peculiar antitumor effects of immunotherapy, a number of immune-related response criteria were developed. As a general principle, by these criteria, the initial increase in tumor burden or the appearance of new lesions is not assessed as PD until confirmation at a subsequent tumor assessment, providing that patients clinical conditions are not deteriorating $[1,3,4]$. Therefore, in selected patients, treatment beyond progression with immunotherapy may be appropriate based on the potential for late responses [5-10].

To assess the rate of atypical responses (i.e. tumor regressions or prolonged disease stabilization after RECI ST-defined PD) in patients with advanced solid tumors who received anti-PD-1 immunotherapy, in 2017 we reviewed the results of 38 clinical trials for a total of 7069 patients [2]. In summary, the proportion of patients treated beyond progression ranged from 11 to $40 \%$; atypical responses were evaluated in 19 clinical trials and 151 atypical responses were observed among 2400 patients, for an overall rate of atypical responses of $6 \%$ [2].

Since then, anti-PD-1 and PD-L1 drugs have been integrated into standard-of-care across many cancer types and many indications. Notably, anti-PD-1/PD-L1 agents also became the keystone of new combinations with chemotherapy, targeted therapy and other immunotherapies, and new clinical trials with anti-PD-1/PD-L1 based regimens have been increasing exponentially.

In view of the uncertainty regarding whether discontinuation of immunotherapy, based on conventional response criteria, may be premature for at least a subset of patients who could derive a late benefit from treatment continuation, most clinical trials of immunotherapies allow for treatment beyond RECIST-defined PD [2]. However, the clinical benefit of treatment beyond progression remains difficult to assess, and whether atypical responses are observed also in regimens including chemotherapy, targeted therapy and other immunotherapies is not clear.

In light of the considerably high number of studies and new combinations, the aim of this systematic review was to update our previously published analysis [2] to further explore the impact of atypical responses and treatment beyond progression in patients receiving an anti-PD-1/PD-L1 based regimen for an advanced solid tumor, and to assess if atypical patterns of response were also observed in patients treated with new combination regimens.

\section{Methods}

Preferred Reporting Items for Systematic Reviews and MetaAnalyses (PRISMA) guidelines were used for the conduct and reporting of this systematic review (Fig. 1) [11].

Prospective clinical trials reporting data on overall response rate (ORR) by immune-related criteria and/or the number of patients treated beyond conventional criteria-defined PD and/or the number of patients achieving a clinical benefit after an initial PD during treatment with regimens including an anti-PD-1/PD-L1 which received the FDA approval for the treatment of an advanced solid tumor were included in this systematic review. The following information was extracted from each report: name of study/study code, ClinicalTrials.gov Identifier, first author and date of publication, study design, treatment regimen, type of cancer, number of patients evaluated for response, time to first imaging, ORR by conventional response evaluation criteria, ORR by immune-related response criteria, response rate after initial PD, treatment beyond progression rate. Only data for arms including an antiPD-1/PD-L1 agent were reported in our review. Supplementary material was also reviewed when available. Abstracts and conference papers were not included in our review. We also excluded other reviews, meta-analyses and retrospective analyses of case series. In the event that a study was published in multiple articles, the most recent data were extracted and reported in the tables.

The definition of atypical response slightly varied across studies, but always followed the principles of the immune-related response criteria proposed by Wolchock et al. in 2009 (i.e. tumor regressions or prolonged disease stabilization after RECIST-defined PD) [1].

Clinical trials were identified by a computerized search of the PubMed data-base with the string ("nivolumab"[MeSH Terms] OR "nivolumab"[All Fields] OR "nivolumab s"[All Fields] OR "pembrolizumab"[Supplementary Concept] OR "pembrolizumab"[All Fields] OR “cemiplimab"[Supplementary Concept] OR “cemiplimab"[All Fields] OR “atezolizumab"[Supplementary Concept] OR "atezolizumab"[All Fields] OR "durvalumab"[Supplementary Concept] OR “durvalumab”[All Fields] OR "avelumab"[Supplementary Concept] OR "avelumab”[All Fields]) and the filter for article type "Clinical Trial". The search was performed on the 24th July 2020.

Data were independently extracted by two investigators (F.S. and A.B.) to ensure homogeneity of collection 


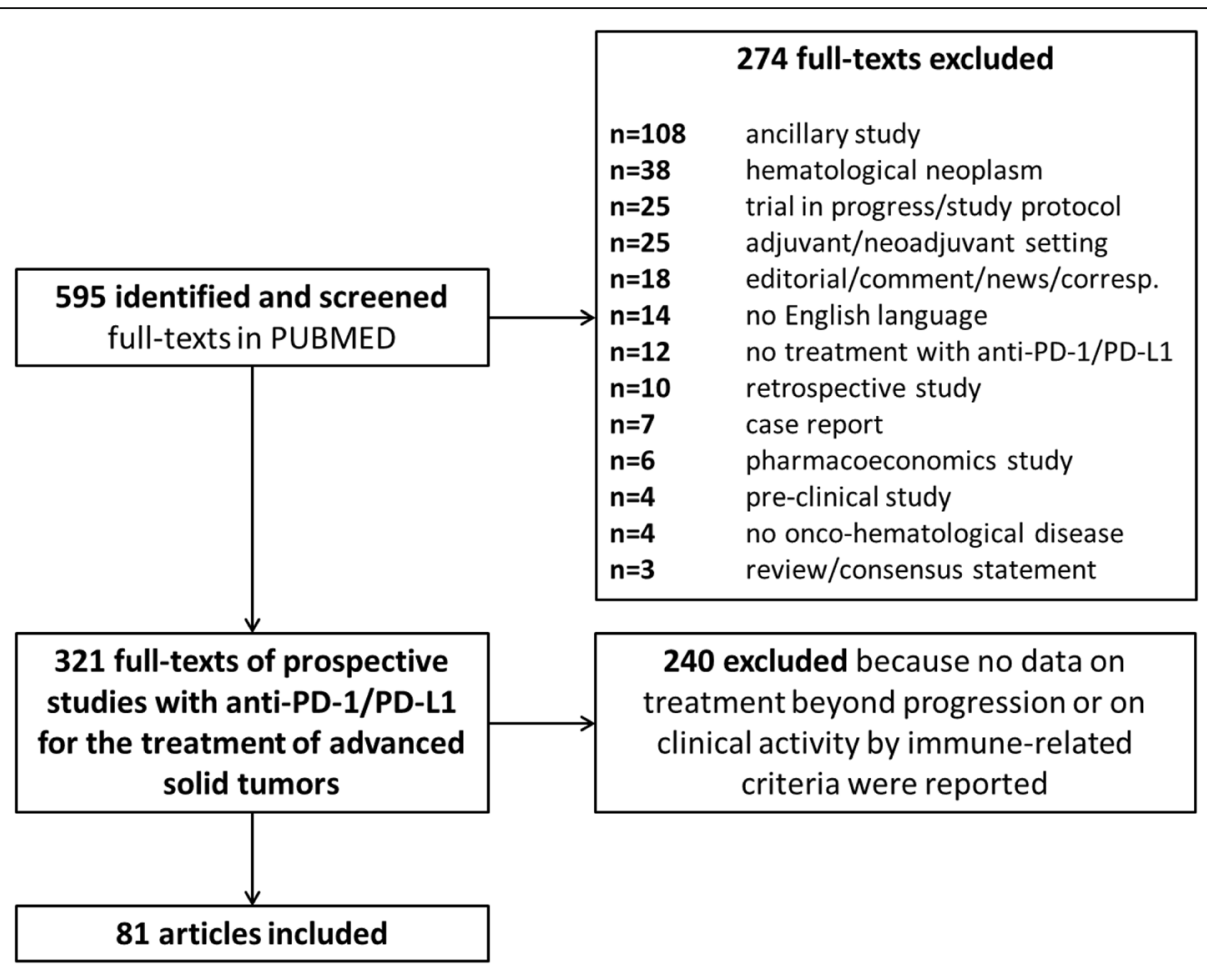

Fig. 1 The PRISMA flowchart summarizing the process for the identification of the eligible studies

and to rule out the effect of subjectivity in data gathering and entry. Disagreements were resolved by iteration, discussion and consensus.

Only descriptive statistics were conducted to obtain a pooled response rate by immune-related response criteria and a pooled rate of patients treated beyond progression for each group of studies (anti-PD-1/PD-L1 as single agents or in combination with chemotherapy, targeted therapy and other immunotherapy).

\section{Results}

Among 321 full-texts of prospective studies investigating antiPD-1/PD-L1 drugs for the treatment of advanced solid tumors, 240 articles were excluded because they did not met the key inclusion criteria of our systematic analysis (i.e. they did not report data on ORR by immune-related criteria and/or on the number of patients treated beyond conventional criteriadefined PD and/or on the number of patients achieving a clinical benefit after an initial PD during treatment with regimens including an anti-PD-1/PD-L1 agent); therefore, only 81 articles were considered eligible and were included in the analysis (Fig. 1), for a total of 9644 patients who received an anti-PD1/PD-L1-based regimen for an advanced solid tumor, and for whom data on immune-related clinical activity was reported.

The results of the studies included in our systematic review are summarized according to treatment regimen (antiPD-1/PD-L1 as single agent, anti-PD-1/PD-L1 in combination with other immunotherapies, anti-PD-1/PD-L1 in combination with targeted therapy, anti-PD-1/PD-L1 in combination with chemotherapy) in Tables 1, 2, 3 and 4.

Forty-four studies investigating anti-PD-1/PD-L1 as single agents were included in our analysis, for a total of 8383 patients (Table 1) [6-10, 12-68]. The number of responses achieved after an initial conventional criteria-defined PD was reported in 35 studies, for a total of 5053 patients evaluated for response; a response after an initial PD was achieved by 232 patients (4.6\%). The rate of patients who received treatment with antiPD-1/PD-L1 as single agents beyond RECIST-defined PD was $31.8 \%$, based on 26 trials reporting this information for a total of 4554 patients. In 18 studies reporting both the number of patients treated beyond PD and the number of responses achieved after initial PD, among 783 subjects who received anti-PD-1/PD-L1 treatment beyond PD, 156 patients (19.9\%) achieved a response after initial RECIST-defined PD. Finally, in 13 studies both the ORR according to conventional and immune-related criteria were reported, and a total of 549 and 674 responses were observed, respectively. Responses after initial RECIST-defined PD were observed across multiple tumor types and varied slightly across the tumor types more represented in our analysis. Specifically, the pooled rate of responses after initial RECI ST-defined PD was $4.0 \%$ for lung cancer, $6.1 \%$ for urothelial cancer, $7.2 \%$ for melanoma and $4.6 \%$ for renal-cell carcinoma. 


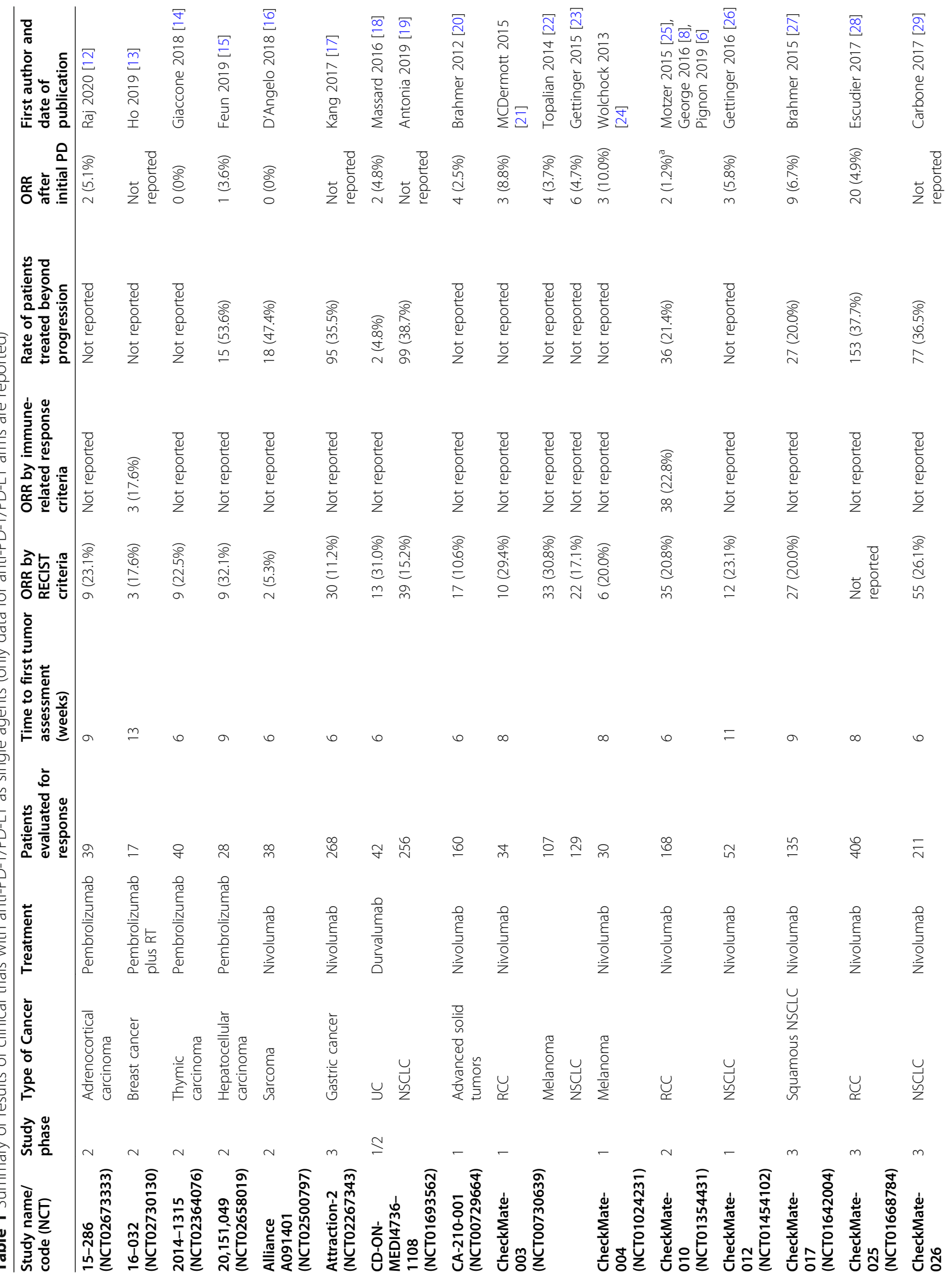




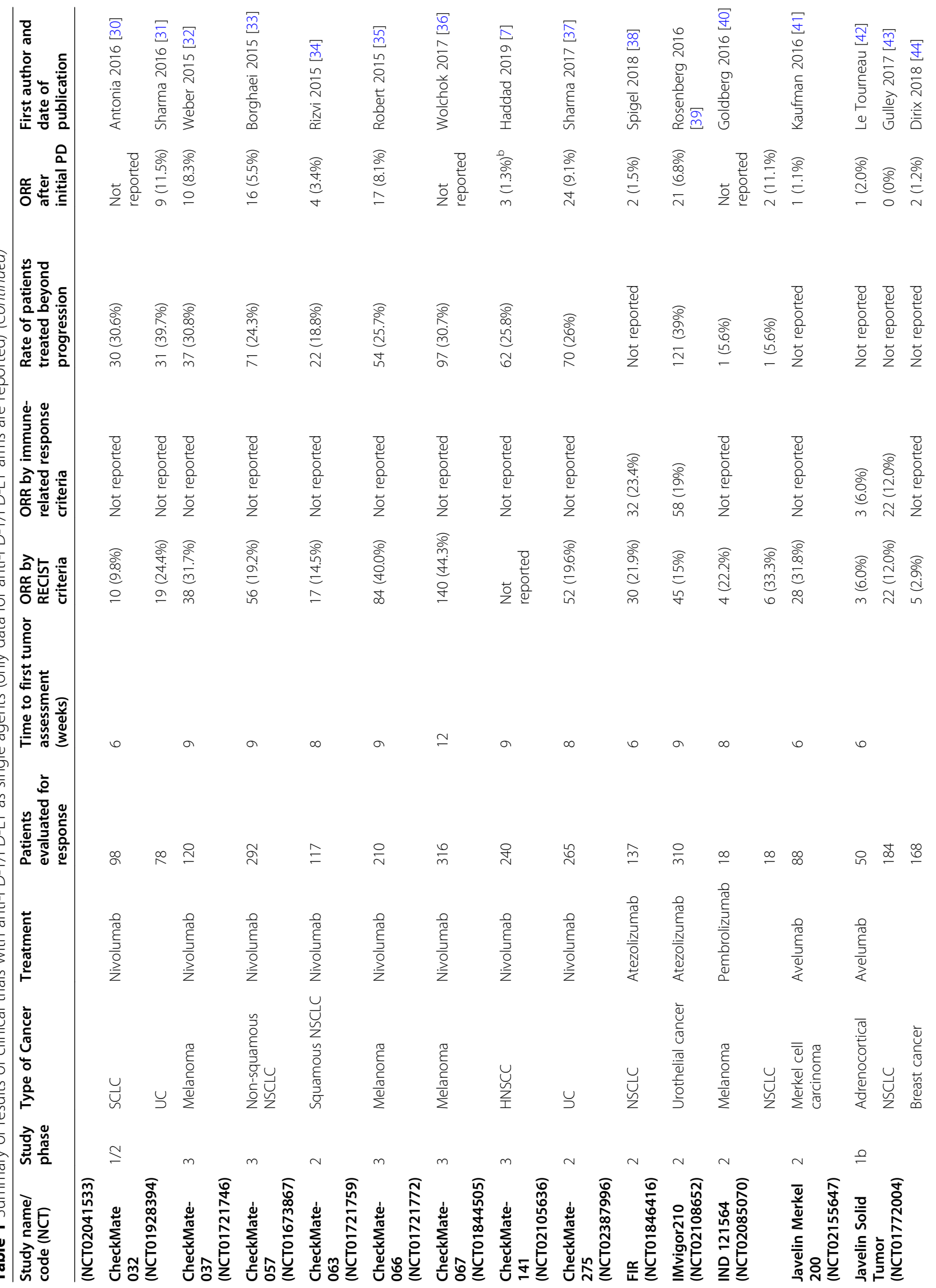




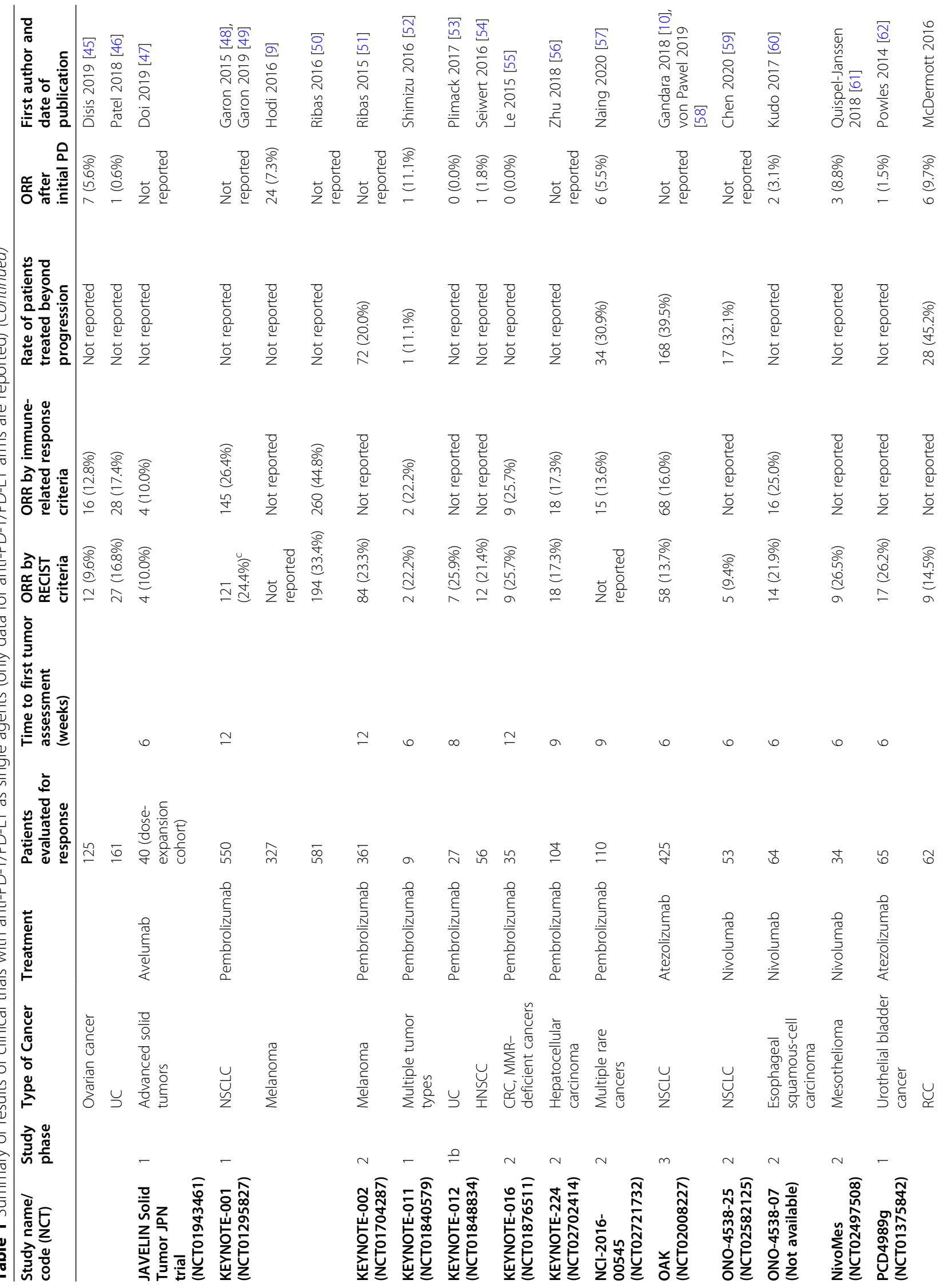




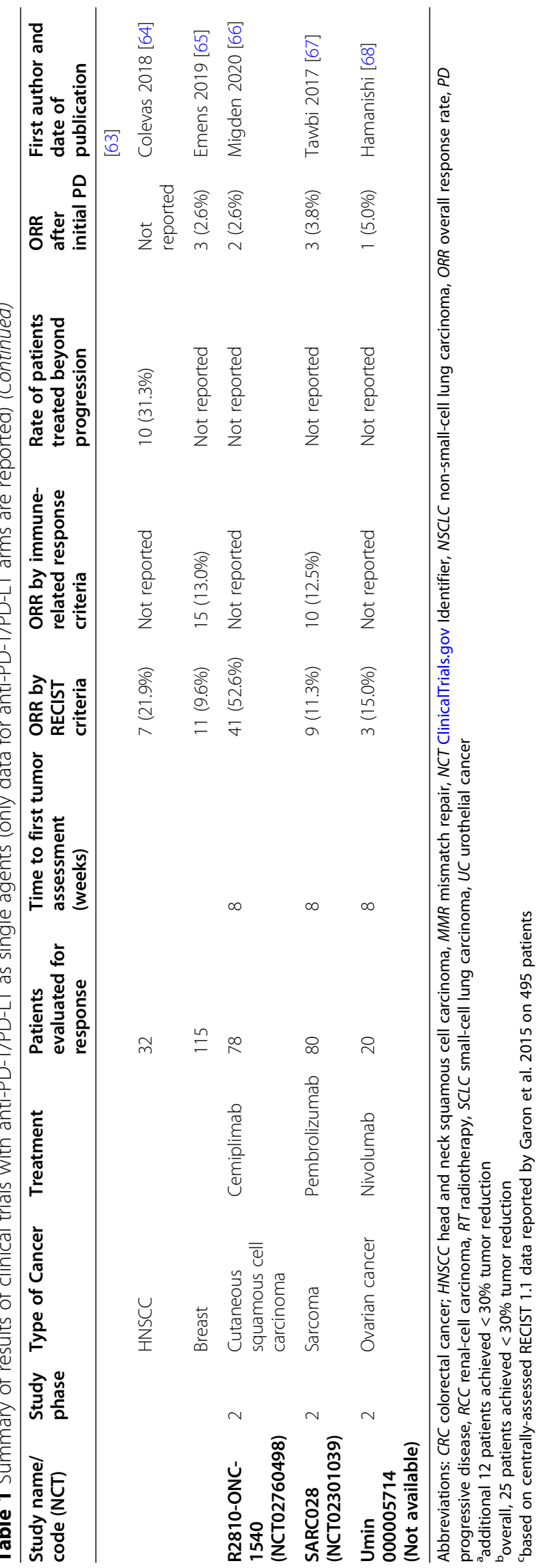




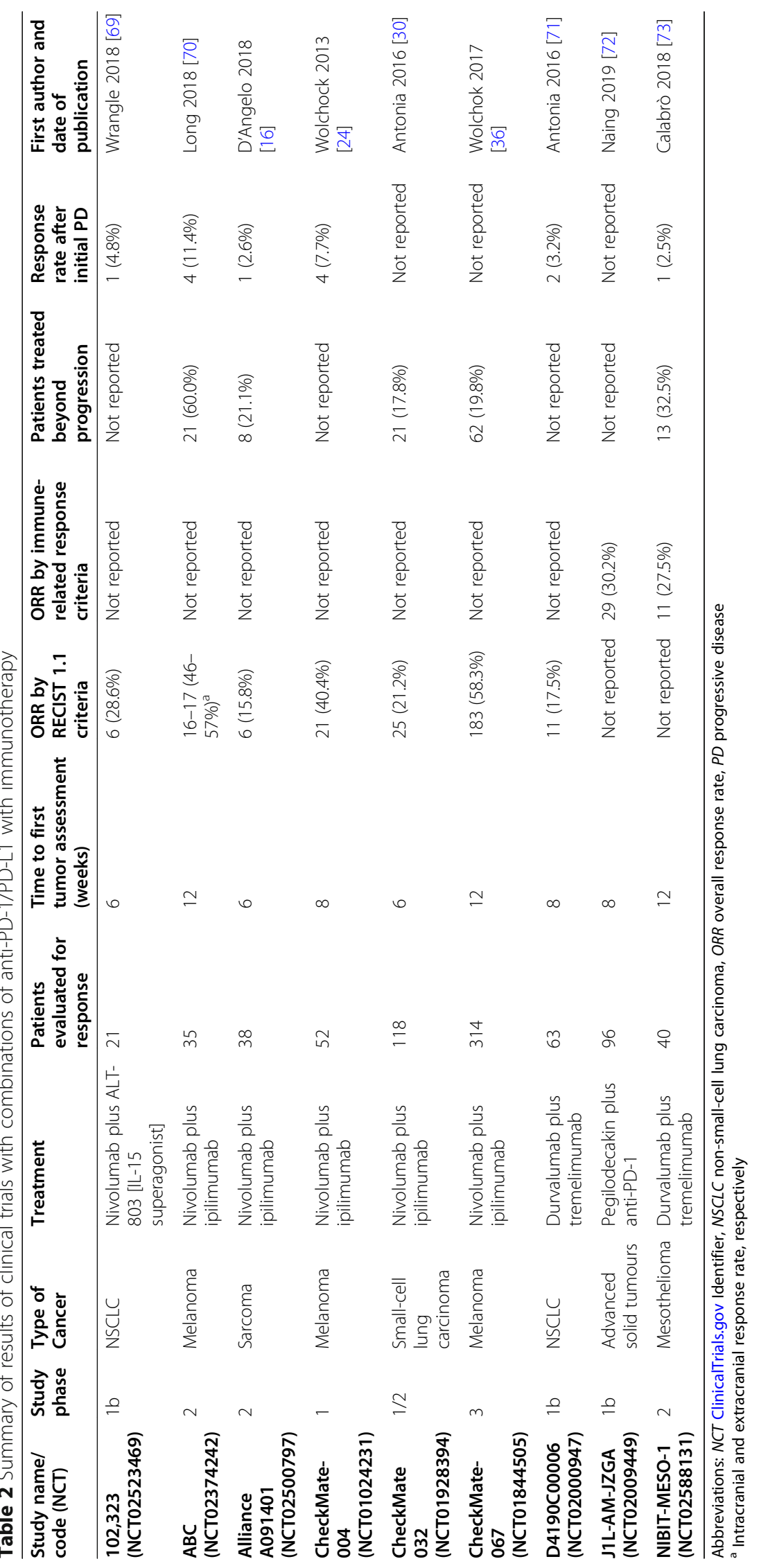


Table 3 Summary of results of clinical trials with combinations of anti-PD-1/PD-L1 with targeted therapy

\begin{tabular}{|c|c|c|c|c|c|c|c|c|c|c|}
\hline $\begin{array}{l}\text { Study name/ } \\
\text { code (NCT) }\end{array}$ & $\begin{array}{l}\text { Study } \\
\text { phase }\end{array}$ & $\begin{array}{l}\text { Type of } \\
\text { Cancer }\end{array}$ & Treatment & $\begin{array}{l}\text { Patients } \\
\text { evaluated } \\
\text { for } \\
\text { response }\end{array}$ & $\begin{array}{l}\text { Time to } \\
\text { first tumor } \\
\text { assessment } \\
\text { (weeks) }\end{array}$ & $\begin{array}{l}\text { ORR } \\
\text { by } \\
\text { RECIST } \\
1.1 \\
\text { criteria } \\
\end{array}$ & $\begin{array}{l}\text { ORR by } \\
\text { immune- } \\
\text { related re- } \\
\text { sponse } \\
\text { criteria }\end{array}$ & $\begin{array}{l}\text { Patients } \\
\text { treated } \\
\text { beyond } \\
\text { progression }\end{array}$ & $\begin{array}{l}\text { Response } \\
\text { rate after } \\
\text { initial PD }\end{array}$ & $\begin{array}{l}\text { First } \\
\text { author and } \\
\text { date of } \\
\text { publication }\end{array}$ \\
\hline $\begin{array}{l}20,150,932 \\
\text { (NCT02636725) }\end{array}$ & 2 & Sarcoma & $\begin{array}{l}\text { Pembrolizumab } \\
\text { plus axitinib }\end{array}$ & 32 & 12 & $\begin{array}{l}8 \\
(25.0 \%)\end{array}$ & 8 (25.0\%) & $4(12.5 \%)$ & $\begin{array}{l}\text { Not } \\
\text { reported }\end{array}$ & $\begin{array}{l}\text { Wilky } 2019 \\
\text { [74] }\end{array}$ \\
\hline $\begin{array}{l}\text { A4061079 } \\
\text { (NCT02133742) }\end{array}$ & $1 b$ & RCC & $\begin{array}{l}\text { Pembrolizumab } \\
\text { plus axitinib }\end{array}$ & 52 & 12 & $\begin{array}{l}38 \\
(73.1 \%)\end{array}$ & $\begin{array}{l}\text { Not } \\
\text { reported }\end{array}$ & $8(15.4 \%)$ & 1 (1.9\%) & $\begin{array}{l}\text { Atkins } 2018 \\
{[75]}\end{array}$ \\
\hline $\begin{array}{l}\text { BTCRC-GU14- } \\
003 \\
\text { (NCT02348008) }\end{array}$ & $1 b / 2$ & RCC & $\begin{array}{l}\text { Pembrolizuamb } \\
\text { plus } \\
\text { bevacizumab }\end{array}$ & 58 & 6 & $\begin{array}{l}33 \\
(56.9 \%)\end{array}$ & $\begin{array}{l}\text { Not } \\
\text { reported }\end{array}$ & 7 (12.1\%) & $\begin{array}{l}\text { Not } \\
\text { reported }\end{array}$ & $\begin{array}{l}\text { Dudek } 2020 \\
\text { [76] }\end{array}$ \\
\hline $\begin{array}{l}\text { CheckMate- } \\
012 \\
\text { (NCT01454102) }\end{array}$ & 1 & NSCLC & $\begin{array}{l}\text { Nivolumab Plus } \\
\text { erlotinib }\end{array}$ & 20 & 11 & $\begin{array}{l}3 \\
(15.0 \%)\end{array}$ & $\begin{array}{l}\text { Not } \\
\text { reported }\end{array}$ & $\begin{array}{l}\text { Not } \\
\text { reported }\end{array}$ & $1(5.0 \%)$ & $\begin{array}{l}\text { Gettinger } \\
2018 \text { [77] }\end{array}$ \\
\hline $\begin{array}{l}\text { GP28328 } \\
\text { (NCT01633970) }\end{array}$ & $1 b$ & $\mathrm{RCC}$ & $\begin{array}{l}\text { Atezolizumab } \\
\text { plus } \\
\text { bevacizumab }\end{array}$ & 10 & 6 & $\begin{array}{l}4 \\
(40.0 \%)\end{array}$ & $\begin{array}{l}\text { Not } \\
\text { reported }\end{array}$ & 2 (20.0\%) & 1 (10.0\%) & $\begin{array}{l}\text { Wallin } 2016 \\
\text { [78] }\end{array}$ \\
\hline $\begin{array}{l}\text { KEYNOTE-146 } \\
\text { (NCT02501096) }\end{array}$ & $1 b / 2$ & $\begin{array}{l}\text { Endometrial } \\
\text { cancer }\end{array}$ & $\begin{array}{l}\text { Pembrolizumab } \\
\text { plus lenvatinib }\end{array}$ & 108 & 6 & $\begin{array}{l}44 \\
(40.7 \%)\end{array}$ & 47 (43.5\%) & $\begin{array}{l}\text { Not } \\
\text { reported }\end{array}$ & $\begin{array}{l}\text { Not } \\
\text { reported }\end{array}$ & $\begin{array}{l}\text { Makker } \\
2020 \text { [79] }\end{array}$ \\
\hline
\end{tabular}

Abbreviations: NCT ClinicalTrials.gov Identifier, NSCLC non-small-cell lung carcinoma, ORR overall response rate, $P D$ progressive disease, $R C C$ renal-cell carcinoma

Nine studies of clinical trials with immunotherapy combination regimens including an anti-PD-1/PD-L1 agent were included in our systematic review, for a total of 777 patients (Table 2) [16, 24, 30, 36, 69-73]. In 6 trials reporting response rate after initial PD, 13/249 patients (5.2\%) achieved a response after initial RECISTdefined PD. The rate of patients treated beyond PD was $22.9 \%$, based on 5 studies reporting this information for a total of 545 patients. In 3 trials reporting both the number of patients treated beyond PD and the number of responses achieved after initial $\mathrm{PD}$, among 42 subjects who received an anti-PD-1/PD-L1-based immunotherapy combination treatment beyond PD, 6 patients (14.3\%) achieved a response after an initial PD. No combination immunotherapy trials reported both the ORR according to conventional and immune-related criteria.

Six studies investigating treatment with anti-PD-1/PDL1 in combination with targeted agents were included in the analysis, for a total of 280 patients (Table 3) [74-79]. Three responses $(3.7 \%)$ after initial PD were observed in 3 trials reporting this information; 21/152 patients (13.8\%) were treated beyond PD. Only in 2 trials both response rate after initial $\mathrm{PD}$ and rate of patients treated beyond PD were reported, with $2 / 10$ subjects (20\%) achieving response after initial RECIST-defined PD. In the 2 trials reporting both RECIST-defined ORR and ORR by immune-related criteria, 52 and 55 patients achieved a response, respectively.

In the 5 trials of anti-PD-1/PD-L1 in combination with chemotherapy, 6 (2.9\%) responses after PD were achieved in a total of 204 patients evaluated for response (Table 4) [80-84]. Based on 2 studies reporting this information, $18 / 83$ patients $(21.7 \%)$ were treated beyond
PD, and among these 18 patients, 4 (22.2\%) achieved a response after an initial PD.

Overall, based on 35 trials included in our analysis reporting data on unconventional responses, 254 responses after an initial RECIST-defined PD were observed among 5588 patients, for an overall rate of $4.6 \%$. The overall rate of patients receiving treatment beyond PD was $30.2 \%$ based on 36 trials (5334 patients), and the overall rate of patients who achieved a response after initial RECIST-defined PD among those treated beyond PD was $19.7 \%$ (25 trials, 853 patients). Finally, in 17 trials (2800 patients) reporting ORR by both conventional and immune-related criteria, 604 and 733 responses were achieved, respectively.

\section{Discussion}

In a pooled analysis of individual patient data made by the US Food and Drug Administration (FDA) in 2018, all submissions of trial reports and data in support of marketing applications for anti-PD-1 drugs as single agent or in combination with other drugs for the treatment of patients with advanced melanoma that allowed for continuation of treatment beyond RECIST-defined PD were analyzed to investigate the effect of treatment beyond PD and to define which subset of patients derive benefit from extended treatment. The finding of this study showed that among the 8 multicenter clinical trials included in the review for a total of 2624 patients receiving immunotherapy, 692/1361 patients (51\%) received anti-PD-1 treatment beyond RECIST-defined PD, and 95/500 evaluable patients (19\%) had a response after initial RECIST-defined PD, representing 14\% of the 692 patients treated beyond PD and 4\% of all 2624 patients 


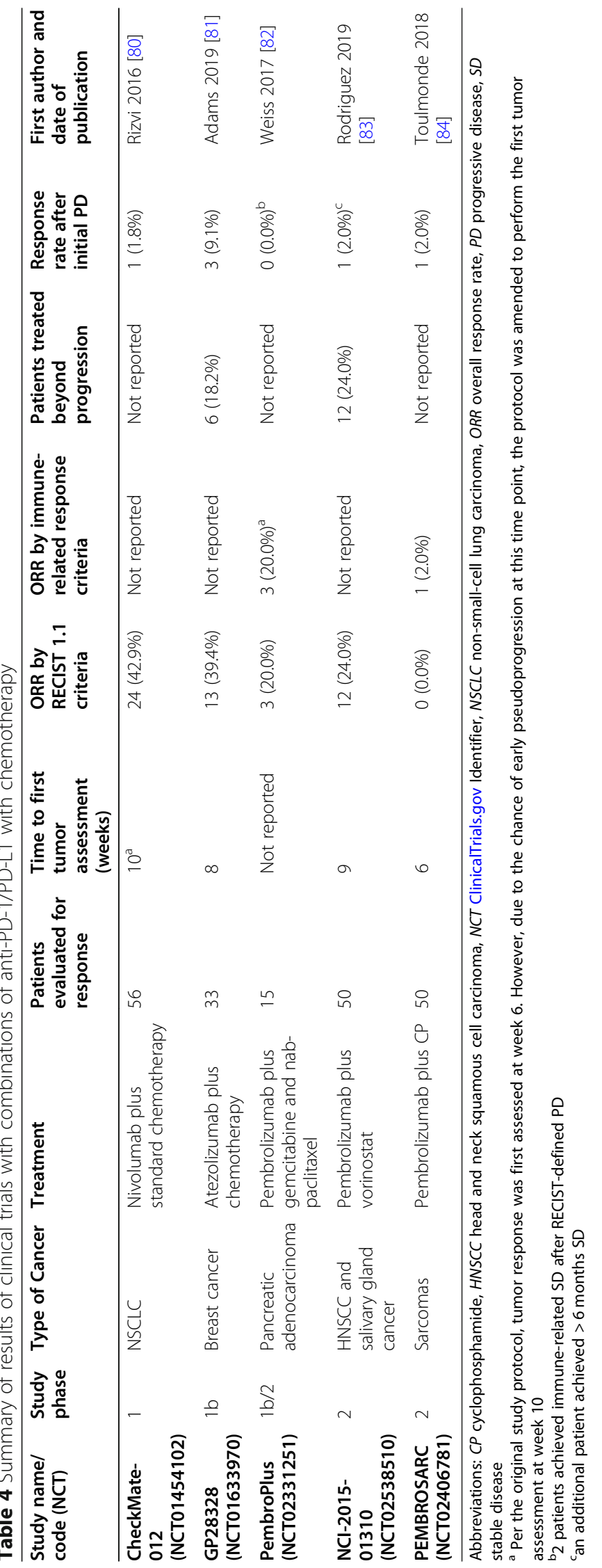


treated with immunotherapy [5]. Based on these results, the authors concluded that treatment beyond PD could not be recommended because the clinical benefit remained to be proven, but that might be appropriate for selected patients identified by specific criteria at the time of progression [5].

In our current systematic review, we found an overall rate of $4.6 \%$ of responses after initial RECIST-defined $\mathrm{PD}$, similar to that reported by the individual patient data pooled analysis made by the FDA in patients with melanoma (4\%) [5]. In our analysis, we found that responses after initial RECIST-defined PD may be achieved across multiple tumor types and multiple treatment regimens based on anti-PD-1/PD-L1 agents, including combinations with targeted therapy, chemotherapy and other immunotherapy. Our results suggested that the impact of immunotherapy treatment beyond RECIST-defined PD is similar regardless of treatment regimens. Notably, the overall rate of patients treated beyond PD achieving a subsequent response was also similar to that reported by the FDA in advanced melanoma (19.7 and 19\%, respectively) [5]. The pooled rate of response after RECIST-defined PD was higher for melanoma (7.2\%) than lung cancer (4.0\%), which may reflect the higher conventional RECIST-defined response rate observed for anti-PD-1/PD-L1 treatment as single agent in melanoma patients as compared as patients with lung cancer.

Despite treatment beyond RECIST-defined PD was allowed in the vast majority of clinical trials analyzed during our literature search (>90\%; data not shown), we found that data on treatment beyond PD and immunerelated anti-tumor clinical activity was largely underreported, with only 81 articles meeting our inclusion criteria among 321 prospective trials full-texts analyzed, for a rate of $25 \%$. In addition to that, partial results were often reported, with only a fraction of articles reporting data on both the rate of patients treated beyond PD and those who achieved a response after initial RECIST-defined PD, representing a limitation of our analysis. Other limitations of our study are the heterogeneity of the included studies in terms of design, populations, treatment regimens, time to first tumor assessment and response evaluation, and the small sample size for the groups of patients treated with combination treatments. Moreover, the impact of treatment beyond PD may have been underestimated because long-lasting disease stabilizations were not included. Some pseudoprogressions may be associated to an early imaging (i.e. 4-6 weeks); nevertheless, in the studies included in our analysis, time to first tumor assessment was never lower than 6 weeks, ranging from 6 to 12 weeks (with the exception of one study with a very small sample size, where first evaluation was performed at 13 weeks), and responses after
RECIST-defined PD were observed regardless of time to first tumor assessment.

Despite these limitations, the results of our systematic review highlight the clinical relevance of responses to anti-PD-1/PD-L1-based regimens after initial RECISTdefined $\mathrm{PD}$, and support further investigation into the development of tools that may assist clinicians for the selection of patients who may derive a benefit from extended immunotherapy treatment beyond RECIST-defined PD. Circulating tumor DNA has emerged as a promising blood-based biomarker for monitoring disease status of patients with advanced cancers, and may play an important predictive role into differentiating pseudoprogressions from true progressions, as observed in a cohort of 125 patients with advanced melanoma who were treated with anti-PD-1 antibodies [85].

Immune-related response criteria were developed to facilitate consistent trial design and data collection; however, most publications provided only partial information regarding immune-related clinical activity, or did not provide any information at all, despite the option of treatment beyond $\mathrm{PD}$ and response evaluation by immune-related criteria being mentioned in the study protocols, highlighting the need of a more comprehensive report of such data in trials investigating immunotherapy for the treatment of patients with advanced tumors.

\section{Abbreviations}

ORR: Overall response rate; PD: Progressive disease; SD: Disease stabilization

\section{Acknowledgements}

None.

\section{Authors' contributions}

FS and $A B$ independently extracted data; FS and PQ made substantial contributions to the conception and design of the work; All authors made substantial contributions to the analysis and interpretation of data; All authors made substantial contributions to drafting and revising the work. The authors read and approved the final manuscript.

\section{Funding}

No funding.

Availability of data and materials

All data generated or analysed during this study are included in this published article.

\section{Declarations}

Ethics approval and consent to participate Not applicable.

\section{Consent for publication}

Not applicable.

\section{Competing interests}

FS received lecture fees from Roche, MSD, BMS, Novartis, Sanofi, Sun Pharma, Merck and Pierre Fabre, and served on advisory boards of Novartis, MSD and Sun Pharma; PQ received lecture fees from Roche, MSD, BMS, Novartis,

Sanofi, Sun Pharma, Merck and Pierre Fabre, and served on advisory boards of Roche, MSD, BMS, Novartis, Sanofi, Sun Pharma, Merck and Pierre Fabre. All other authors declare that they have no competing interests. 


\section{Author details}

${ }^{1}$ Medical Oncology 2, IRCCS Ospedale Policlinico San Martino, Largo R. Benzi 10, 16132 Genoa, Italy. ${ }^{2}$ Melanoma, Sarcoma \& Rare Tumors Division, European Institute of Oncology (IEO), Milan, Italy.

Received: 17 November 2020 Accepted: 9 April 2021 Published online: 17 April 2021

\section{References}

1. Wolchok JD, Hoos A, O'Day S, et al. Guidelines for the evaluation of immune therapy activity in solid tumors: immune-related response criteria. Clin Cancer Res. 2009;15(23):7412-20. https://doi.org/10.1158/1078-0432. CCR-09-1624.

2. Queirolo P, Spagnolo F. Atypical responses in patients with advanced melanoma, lung cancer, renal-cell carcinoma and other solid tumors treated with anti-PD-1 drugs: a systematic review. Cancer Treat Rev. 2017;59:71-8. https://doi.org/10.1016/j.ctrv.2017.07.002.

3. Hoos A, Wolchok JD, Humphrey RW, Hodi FS. $<$ em $>C C R</ e m>20^{\text {th }}$ Anniversary Commentary: Immune-Related Response Criteria-Capturing Clinical Activity in Immuno-Oncology. Clin Cancer Res. 2015;21(22):4989.

4. Seymour L, Bogaerts J, Perrone A, Ford R, Schwartz LH, Mandrekar S, et al. iRECIST: guidelines for response criteria for use in trials testing immunotherapeutics. Lancet Oncol. 2017;18(3):e143-52. https://doi.org/10.1 016/S1470-2045(17)30074-8.

5. Beaver JA, Hazarika M, Mulkey F, et al. Patients with melanoma treated with an anti-PD-1 antibody beyond RECIST progression: a US Food and Drug Administration pooled analysis. Lancet Oncol. 2018;19(2):229-39.

6. Pignon J-C, Jegede $\mathrm{O}$, Shukla SA, et al. irRECIST for the evaluation of candidate biomarkers of response to Nivolumab in metastatic clear cell renal cell carcinoma: analysis of a phase II prospective clinical trial. Clin Cancer Res Off J Am Assoc. 2019;25(7):2174-84.

7. Haddad R, Concha-Benavente F, Blumenschein G Jr, et al. Nivolumab treatment beyond RECIST-defined progression in recurrent or metastatic squamous cell carcinoma of the head and neck in CheckMate 141: a subgroup analysis of a randomized phase 3 clinical trial. Cancer. 2019; 125(18):3208-18.

8. George S, Motzer RJ, Hammers HJ, et al. Safety and efficacy of Nivolumab in patients with metastatic renal cell carcinoma treated beyond progression: a subgroup analysis of a randomized clinical trial. JAMA Oncol. 2016;2(9): 1179-86.

9. Hodi FS, Hwu W-J, Kefford R, Weber JS, Daud A, Hamid O, et al. Evaluation of immune-related response criteria and RECIST v1.1 in patients with advanced melanoma treated with Pembrolizumab. J Clin Oncol. 2016;34(13): 1510-7. https://doi.org/10.1200/JCO.2015.64.0391.

10. Gandara DR, von Pawel J, Mazieres J, Sullivan R, Helland $\AA$, Han JY, et al. Atezolizumab treatment beyond progression in advanced NSCLC: results from the randomized, phase III OAK study. J Thorac Oncol. 2018;13(12): 1906-18. https://doi.org/10.1016/j.jtho.2018.08.2027.

11. Moher D, Liberati A, Tetzlaff J, Altman DG, The PRISMA Group. Preferred reporting items for systematic reviews and meta-analyses: the PRISMA statement. PLoS Med. 2009;6(7):e1000097. https://doi.org/10.1371/journal. pmed. 1000097.

12. Raj N, Zheng Y, Kelly V, Katz SS, Chou J, Do RKG, et al. PD-1 blockade in advanced adrenocortical carcinoma. J Clin Oncol. 2019;38(1):71-80. https:// doi.org/10.1200/JCO.19.01586.

13. Ho AY, Barker CA, Arnold BB, Powell SN, Hu ZI, Gucalp A, et al. A phase 2 clinical trial assessing the efficacy and safety of pembrolizumab and radiotherapy in patients with metastatic triple-negative breast cancer. Cancer. 2020;126(4):850-60. https://doi.org/10.1002/cncr.32599.

14. Giaccone G, Kim C, Thompson J, et al. Pembrolizumab in patients with thymic carcinoma: a single-arm, single-Centre, phase 2 study. Lancet Oncol. 2018;19(3):347-55.

15. Feun LG, Li Y-Y, Wu C, et al. Phase 2 study of pembrolizumab and circulating biomarkers to predict anticancer response in advanced, unresectable hepatocellular carcinoma. Cancer. 2019;125(20):3603-14.

16. D'Angelo SP, Mahoney MR, Van Tine BA, et al. Nivolumab with or without ipilimumab treatment for metastatic sarcoma (Alliance A091401): two openlabel, non-comparative, randomised, phase 2 trials. Lancet Oncol. 2018;19(3): 416-26.

17. Kang Y-K, Boku N, Satoh T, et al. Nivolumab in patients with advanced gastric or gastro-oesophageal junction cancer refractory to, or intolerant of, at least two previous chemotherapy regimens (ONO-4538-12, ATTRACTION2): a randomised, double-blind, placebo-controlled, phase 3 trial. Lancet. 2017;390(10111):2461-71.

18. Massard C, Gordon MS, Sharma S, Rafii S, Wainberg ZA, Luke J, et al. Safety and efficacy of Durvalumab (MED|4736), an anti-programmed cell death Ligand-1 immune checkpoint inhibitor, in patients with advanced Urothelial bladder Cancer. J Clin Oncol Off J Am Soc Clin Oncol. 2016;34(26):3119-25. https://doi.org/10.1200/JCO.2016.67.9761.

19. Antonia SJ, Balmanoukian A, Brahmer J, Ou SHI, Hellmann MD, Kim SW, et al. Clinical activity, tolerability, and Long-term follow-up of Durvalumab in patients with advanced NSCLC. J Thorac Oncol. 2019;14(10):1794-806. https://doi.org/10.1016/j.jtho.2019.06.010.

20. Brahmer JR, Tykodi SS, Chow LQM, Hwu WJ, Topalian SL, Hwu P, et al. Safety and activity of anti-PD-L1 antibody in patients with advanced Cancer. N Engl J Med. 2012;366(26):2455-65. https://doi.org/10.1056/ NEJMoa1200694.

21. McDermott DF, Drake CG, Sznol M, et al. Survival, durable response, and Long-term safety in patients with previously treated advanced renal cell carcinoma receiving Nivolumab. J Clin Oncol Off J Am Soc Clin Oncol. 2015; 33(18):2013-20. https://doi.org/10.1200/JCO.2014.58.1041.

22. Topalian SL, Sznol M, McDermott DF, et al. Survival, durable tumor remission, and long-term safety in patients with advanced melanoma receiving nivolumab. J Clin Oncol Off J Am Soc Clin Oncol. 2014;32(10): 1020-30.

23. Gettinger SN, Horn L, Gandhi L, et al. Overall survival and Long-term safety of Nivolumab (anti-programmed death 1 antibody, BMS-936558, ONO-4538) in patients with previously treated advanced non-small-cell lung Cancer. J Clin Oncol Off J Am Soc Clin Oncol. 2015;33(18):2004-12

24. Wolchok JD, Kluger H, Callahan MK, Postow MA, Rizvi NA, Lesokhin AM, et al. Nivolumab plus ipilimumab in advanced melanoma. N Engl J Med. 2013;369(2):122-33. https://doi.org/10.1056/NEJMoa1302369.

25. Motzer RJ, Rini Bl, McDermott DF, et al. Nivolumab for metastatic renal cell carcinoma: results of a randomized phase II trial. J Clin Oncol Off J Am Soc Clin Oncol. 2015;33(13):1430-7. https://doi.org/10.1200/JC0.2014.59.0703.

26. Gettinger S, Rizvi NA, Chow LQ, Borghaei H, Brahmer J, Ready N, et al. Nivolumab Monotherapy for first-line treatment of advanced non-small-cell lung Cancer. J Clin Oncol Off J Am Soc Clin Oncol. 2016;34(25):2980-7. https://doi.org/10.1200/JCO.2016.66.9929.

27. Brahmer J, Reckamp KL, Baas P, Crinò L, Eberhardt WEE, Poddubskaya E, et al. Nivolumab versus Docetaxel in advanced squamous-cell non-smallcell lung Cancer. N Engl J Med. 2015;373(2):123-35. https://doi.org/10.1056/ NEJMoa1504627.

28. Escudier B, Motzer RJ, Sharma P, et al. Treatment beyond progression in patients with advanced renal cell carcinoma treated with Nivolumab in CheckMate 025. Eur Urol. 2017;72(3):368-76.

29. Carbone DP, Reck M, Paz-Ares L, et al. First-line Nivolumab in stage IV or recurrent non-small-cell lung Cancer. N Engl J Med. 2017;376(25):2415-26.

30. Antonia SJ, López-Martin JA, Bendell J, et al. Nivolumab alone and nivolumab plus ipilimumab in recurrent small-cell lung cancer (CheckMate 032): a multicentre, open-label, phase 1/2 trial. Lancet Oncol. 2016;17(7):883-95.

31. Sharma $\mathrm{P}$, Callahan MK, Bono $\mathrm{P}$, et al. Nivolumab monotherapy in recurrent metastatic urothelial carcinoma (CheckMate 032): a multicentre, open-label, two-stage, multi-arm, phase 1/2 trial. Lancet Oncol. 2016;17(11):1590-8.

32. Weber JS, D'Angelo SP, Minor D, et al. Nivolumab versus chemotherapy in patients with advanced melanoma who progressed after anti-CTLA-4 treatment (CheckMate 037): a randomised, controlled, open-label, phase 3 trial. Lancet Oncol. 2015;16(4):375-84.

33. Borghaei H, Paz-Ares L, Horn L, Spigel DR, Steins M, Ready NE, et al. Nivolumab versus Docetaxel in advanced nonsquamous non-small-cell lung Cancer. N Engl J Med. 2015;373(17):1627-39. https://doi.org/10.1056/ NEJMoa1507643.

34. Rizvi NA, Mazières J, Planchard D, Stinchcombe TE, Dy GK, Antonia SJ, et al. Activity and safety of nivolumab, an anti-PD-1 immune checkpoint inhibitor, for patients with advanced, refractory squamous non-small-cell lung cancer (CheckMate 063): a phase 2, single-arm trial. Lancet Oncol. 2015;16(3):25765. https://doi.org/10.1016/S1470-2045(15)70054-9.

35. Robert C, Long GV, Brady B, et al. Nivolumab in previously untreated melanoma without BRAF mutation. N Engl J Med. 2014;372(4):320-30.

36. Wolchok JD, Chiarion-Sileni V, Gonzalez R, et al. Overall survival with combined Nivolumab and Ipilimumab in advanced melanoma. N Engl J Med. 2017:377(14):1345-56. 
37. Sharma P, Retz M, Siefker-Radtke A, et al. Nivolumab in metastatic urothelial carcinoma after platinum therapy (CheckMate 275): a multicentre, singlearm, phase 2 trial. Lancet Oncol. 2017;18(3):312-22.

38. Spigel DR, Chaft JE, Gettinger S, Chao BH, Dirix L, Schmid P, et al. FIR: efficacy, safety, and biomarker analysis of a phase II open-label study of Atezolizumab in PD-L1-selected patients with NSCLC. J Thorac Oncol. 2018; 13(11):1733-42. https://doi.org/10.1016/j.jtho.2018.05.004.

39. Rosenberg JE, Hoffman-Censits J, Powles T, van der Heijden MS, Balar AV, Necchi A, et al. Atezolizumab in patients with locally advanced and metastatic urothelial carcinoma who have progressed following treatment with platinum-based chemotherapy: a single-arm, multicentre, phase 2 trial. Lancet Lond Engl. 2016;387(10031):1909-20. https://doi.org/10.1016/S01406736(16)00561-4.

40. Goldberg SB, Gettinger SN, Mahajan A, Chiang AC, Herbst RS, Sznol M, et al. Pembrolizumab for patients with melanoma or non-small-cell lung cancer and untreated brain metastases: early analysis of a non-randomised, openlabel, phase 2 trial. Lancet Oncol. 2016;17(7):976-83. https://doi.org/10.1016/ S1470-2045(16)30053-5.

41. Kaufman HL, Russell J, Hamid O, et al. Avelumab in patients with chemotherapy-refractory metastatic Merkel cell carcinoma: a multicentre, single-group, open-label, phase 2 trial. Lancet Oncol. 2016;17(10):1374-85.

42. Le Tourneau C, Hoimes C, Zarwan C, et al. Avelumab in patients with previously treated metastatic adrenocortical carcinoma: phase $1 \mathrm{~b}$ results from the JAVELIN solid tumor trial. J Immunother Cancer. 2018;6(1):111. https://doi.org/10.1186/s40425-018-0424-9.

43. Gulley JL, Rajan A, Spigel DR, et al. Avelumab for patients with previously treated metastatic or recurrent non-small-cell lung cancer (JAVELIN solid tumor): dose-expansion cohort of a multicentre, open-label, phase $1 \mathrm{~b}$ trial. Lancet Oncol. 2017;18(5):599-610.

44. Dirix LY, Takacs I, Jerusalem G, Nikolinakos P, Arkenau HT, Forero-Torres A, et al. Avelumab, an anti-PD-L1 antibody, in patients with locally advanced or metastatic breast cancer: a phase 1b JAVELIN solid tumor study. Breast Cancer Res Treat. 2018;167(3):671-86. https://doi.org/10.1007/s10549-017-4 537-5.

45. Disis ML, Taylor MH, Kelly K, Beck JT, Gordon M, Moore KM, et al. Efficacy and safety of Avelumab for patients with recurrent or refractory ovarian Cancer: phase $1 \mathrm{~b}$ results from the JAVELIN solid tumor trial. JAMA Oncol. 2019;5(3):393-401. https://doi.org/10.1001/jamaoncol.2018.6258.

46. Patel MR, Ellerton J, Infante JR, et al. Avelumab in metastatic urothelial carcinoma after platinum failure (JAVELIN solid tumor): pooled results from two expansion cohorts of an open-label, phase 1 trial. Lancet Oncol. 2018; 19(1):51-64.

47. Doi T, Iwasa S, Muro K, et al. Phase 1 trial of avelumab (anti-PD-L1) in Japanese patients with advanced solid tumors, including dose expansion in patients with gastric or gastroesophageal junction cancer: the JAVELIN solid tumor JPN trial. Gastric Cancer Off J Int Gastric Cancer Assoc Jpn Gastric Cancer Assoc. 2019;22(4):817-27.

48. Garon EB, Rizvi NA, Hui R, et al. Pembrolizumab for the treatment of nonsmall-cell lung Cancer. N Engl J Med. 2015;372(21):2018-28.

49. Garon EB, Hellmann MD, Rizvi NA, Carcereny E, Leighl NB, Ahn MJ, et al. Five-year overall survival for patients with advanced non-small-cell lung Cancer treated with Pembrolizumab: results from the phase I KEYNOTE-001 study. J Clin Oncol Off J Am Soc Clin Oncol. 2019;37(28):2518-27. https:// doi.org/10.1200/JCO.19.00934.

50. Ribas A, Hamid O, Daud A, Hodi FS, Wolchok JD, Kefford R, et al. Association of Pembrolizumab with Tumor Response and Survival among Patients with Advanced Melanoma. JAMA. 2016;315(15):1600-9. https://doi.org/10.1001/jama.2016.4059.

51. Ribas A, Puzanov I, Dummer R, Schadendorf D, Hamid O, Robert C, et al. Pembrolizumab versus investigator-choice chemotherapy for ipilimumabrefractory melanoma (KEYNOTE-002): a randomised, controlled, phase 2 trial. Lancet Oncol. 2015;16(8):908-18. https://doi.org/10.1016/S1470-2045(1 5)00083-2.

52. Shimizu T, Seto T, Hirai F, Takenoyama M, Nosaki K, Tsurutani J, et al. Phase 1 study of pembrolizumab (MK-3475; anti-PD-1 monoclonal antibody) in Japanese patients with advanced solid tumors. Investig New Drugs. 2016; 34(3):347-54. https://doi.org/10.1007/s10637-016-0347-6.

53. Plimack ER, Bellmunt J, Gupta S, Berger R, Chow LQM, Juco J, et al. Safety and activity of pembrolizumab in patients with locally advanced or metastatic urothelial cancer (KEYNOTE-012): a non-randomised, open-label, phase 1b study. Lancet Oncol. 2017;18(2):212-20. https://doi.org/10.1016/ s1470-2045(17)30007-4.
54. Seiwert TY, Burtness B, Mehra R, Weiss J, Berger R, Eder JP, et al. Safety and clinical activity of pembrolizumab for treatment of recurrent or metastatic squamous cell carcinoma of the head and neck (KEYNOTE-012): an openlabel, multicentre, phase 1b trial. Lancet Oncol. 2016;17(7):956-65. https:// doi.org/10.1016/S1470-2045(16)30066-3.

55. Le DT, Uram JN, Wang H, et al. PD-1 blockade in tumors with mismatchrepair deficiency. N Engl J Med. 2015;372(26):2509-20. https://doi.org/10.1 056/NEJMoa1500596.

56. Zhu AX, Finn RS, Edeline J, Cattan S, Ogasawara S, Palmer D, et al. Pembrolizumab in patients with advanced hepatocellular carcinoma previously treated with sorafenib (KEYNOTE-224): a non-randomised, openlabel phase 2 trial. Lancet Oncol. 2018;19(7):940-52. https://doi.org/10.1016/ S1470-2045(18)30351-6.

57. Naing A, Meric-Bernstam F, Stephen B, et al. Phase 2 study of pembrolizumab in patients with advanced rare cancers. J Immunother Cancer. 2020;8(1):e000347.

58. von Pawel J, Bordoni R, Satouchi M, Fehrenbacher L, Cobo M, Han JY, et al. Long-term survival in patients with advanced non-small-cell lung cancer treated with atezolizumab versus docetaxel: results from the randomised phase III OAK study. Eur J Cancer. 2019;107:124-32. https://doi.org/10.1016/j. ejca.2018.11.020.

59. Chen Y-M, Chih-Hsin Yang J, Su W-C, et al. Nivolumab safety and efficacy in advanced, platinum-resistant, non-small cell lung cancer, radical radiotherapy-ineligible patients: a phase II study in Taiwan. J Formos Med Assoc. 2020. https://doi.org/10.1016/j.jfma.2020.01.004.

60. Kudo T, Hamamoto Y, Kato K, et al. Nivolumab treatment for oesophageal squamous-cell carcinoma: an open-label, multicentre, phase 2 trial. Lancet Oncol. 2017;18(5):631-9.

61. Quispel-Janssen J, van der Noort V, de Vries JF, Zimmerman M, Lalezari F, Thunnissen E, et al. Programmed death 1 blockade with Nivolumab in patients with recurrent malignant pleural mesothelioma. J Thorac Oncol. 2018;13(10):1569-76. https://doi.org/10.1016/j.jtho.2018.05.038.

62. Powles T, Eder JP, Fine GD, Braiteh FS, Loriot Y, Cruz C, et al. MPDL3280A (anti-PD-L1) treatment leads to clinical activity in metastatic bladder cancer. Nature. 2014;515(7528):558-62. https://doi.org/10.1038/nature13904.

63. McDermott DF, Sosman JA, Sznol M, et al. Atezolizumab, an antiprogrammed death-ligand 1 antibody, in metastatic renal cell carcinoma: Long-term safety, clinical activity, and immune correlates from a phase la study. J Clin Oncol. 2016;34(8):833-42.

64. Colevas AD, Bahleda R, Braiteh F, et al. Safety and clinical activity of atezolizumab in head and neck cancer: results from a phase I trial. Endog Retroviruses Their Implic Immunother. 2018;29(11):2247-53.

65. Emens LA, Cruz C, Eder JP, et al. Long-term clinical outcomes and biomarker analyses of Atezolizumab therapy for patients with metastatic triple-negative breast Cancer: a phase 1 study. JAMA Oncol. 2019;5(1):74-82.

66. Migden MR, Khushalani NI, Chang ALS, Lewis KD, Schmults CD, HernandezAya $L$, et al. Cemiplimab in locally advanced cutaneous squamous cell carcinoma: results from an open-label, phase 2 , single-arm trial. Lancet Oncol. 2020;21(2):294-305. https://doi.org/10.1016/S1470-2045(19)30728-4.

67. Tawbi HA, Burgess M, Bolejack V, van Tine BA, Schuetze SM, Hu J, et al. Pembrolizumab in advanced soft-tissue sarcoma and bone sarcoma (SARC028): a multicentre, two-cohort, single-arm, open-label, phase 2 trial. Lancet Oncol. 2017;18(11):1493-501. https://doi.org/10.1016/S1470-2045(1 7)30624-1.

68. Hamanishi J, Mandai M, Ikeda T, Minami M, Kawaguchi A, Murayama T, et al. Safety and antitumor activity of anti-PD-1 antibody, Nivolumab, in patients with platinum-resistant ovarian Cancer. J Clin Oncol. 2015;33(34):4015-22. https://doi.org/10.1200/JCO.2015.62.3397.

69. Wrangle JM, Velcheti V, Patel MR, Garrett-Mayer E, Hill EG, Ravenel JG, et al. ALT-803, an IL-15 superagonist, in combination with nivolumab in patients with metastatic non-small cell lung cancer: a non-randomised, open-label, phase 1b trial. Lancet Oncol. 2018;19(5):694-704. https://doi.org/10.1016/S14 70-2045(18)30148-7.

70. Long GV, Atkinson V, Lo S, Sandhu S, Guminski AD, Brown MP, et al. Combination nivolumab and ipilimumab or nivolumab alone in melanoma brain metastases: a multicentre randomised phase 2 study. Lancet Oncol. 2018;19(5):672-81. https://doi.org/10.1016/S1470-2045(18)30139-6.

71. Antonia S, Goldberg SB, Balmanoukian A, Chaft JE, Sanborn RE, Gupta A, et al. Safety and antitumour activity of durvalumab plus tremelimumab in non-small cell lung cancer: a multicentre, phase $1 \mathrm{~b}$ study. Lancet Oncol. 2016;17(3):299-308. https://doi.org/10.1016/S1470-2045(15)00544-6. 
72. Naing A, Wong DJ, Infante JR, Korn WM, Aljumaily R, Papadopoulos KP, et al. Pegilodecakin combined with pembrolizumab or nivolumab for patients with advanced solid tumours (IVY): a multicentre, multicohort, open-label, phase 1b trial. Lancet Oncol. 2019;20(11):1544-55. https://doi.org/10.1016/ S1470-2045(19)30514-5.

73. Calabrò L, Morra A, Giannarelli D, Amato G, D'Incecco A, Covre A, et al. Tremelimumab combined with durvalumab in patients with mesothelioma (NIBIT-MESO-1): an open-label, non-randomised, phase 2 study. Lancet Respir Med. 2018;6(6):451-60. https://doi.org/10.1016/S2213-2600(18)301516.

74. Wilky BA, Trucco MM, Subhawong TK, Florou V, Park W, Kwon D, et al. Axitinib plus pembrolizumab in patients with advanced sarcomas including alveolar soft-part sarcoma: a single-Centre, single-arm, phase 2 trial. Lancet Oncol. 2019;20(6):837-48. https://doi.org/10.1016/S1470-2045(19)30153-6.

75. Atkins MB, Plimack ER, Puzanov I, Fishman MN, McDermott DF, Cho DC, et al. Axitinib in combination with pembrolizumab in patients with advanced renal cell cancer: a non-randomised, open-label, dose-finding, and dose-expansion phase 1b trial. Lancet Oncol. 2018;19(3):405-15. https:// doi.org/10.1016/S1470-2045(18)30081-0.

76. Dudek AZ, Liu LC, Gupta S, Logan TF, Singer EA, Joshi M, et al. Phase Ib/II clinical trial of Pembrolizumab with Bevacizumab for metastatic renal cell carcinoma: BTCRC-GU14-003. J Clin Oncol. 2020;38(11):1138-45. https://doi. org/10.1200/JCO.19.02394.

77. Gettinger S, Hellmann MD, Chow LQM, Borghaei H, Antonia S, Brahmer JR, et al. Nivolumab plus Erlotinib in patients with EGFR-mutant advanced NSCLC. J Thorac Oncol. 2018;13(9):1363-72. https://doi.org/10.1016/j.jtho.201 8.05.015.

78. Wallin JJ, Bendell JC, Funke R, Sznol M, Korski K, Jones S, et al. Atezolizumab in combination with bevacizumab enhances antigen-specific T-cell migration in metastatic renal cell carcinoma. Nat Commun. 2016;7(1):12624. https://doi.org/10.1038/ncomms12624.

79. Makker V, Taylor MH, Aghajanian C, et al. Lenvatinib Plus Pembrolizumab in Patients With Advanced Endometrial Cancer. J Clin Oncol. 2020;38(26):298192.

80. Rizvi NA, Hellmann MD, Brahmer JR, Juergens RA, Borghaei H, Gettinger $\mathrm{S}$, et al. Nivolumab in combination with platinum-based doublet chemotherapy for first-line treatment of advanced non-small-cell lung Cancer. J Clin Oncol Off J Am Soc Clin Oncol. 2016;34(25):2969-79. https:// doi.org/10.1200/JCO.2016.66.9861.

81. Adams S, Diamond JR, Hamilton E, Pohlmann PR, Tolaney SM, Chang CW, et al. Atezolizumab plus nab-paclitaxel in the treatment of metastatic triplenegative breast Cancer with 2-year survival follow-up: a phase $1 \mathrm{~b}$ clinical trial. JAMA Oncol. 2019;5(3):334-42. https://doi.org/10.1001/jamaoncol.2018. 5152.

82. Weiss GJ, Blaydorn L, Beck J, Bornemann-Kolatzki K, Urnovitz H, Schütz E, et al. Phase Ib/II study of gemcitabine, nab-paclitaxel, and pembrolizumab in metastatic pancreatic adenocarcinoma. Investig New Drugs. 2018;36(1): 96-102. https://doi.org/10.1007/s10637-017-0525-1.

83. Rodriguez CP, Wu Q(M), Voutsinas J, et al. A Phase II Trial of Pembrolizumab and Vorinostat in Recurrent Metastatic Head and Neck Squamous Cell Carcinomas and Salivary Gland Cancer. Clin Cancer Res. 2020;26(4):837.

84. Toulmonde M, Penel N, Adam J, et al. Use of PD-1 targeting, macrophage infiltration, and IDO pathway activation in sarcomas: a phase 2 clinical trial. JAMA Oncol. 2018:4(1):93-7.

85. Lee JH, Long GV, Menzies AM, Lo S, Guminski A, Whitbourne K, et al. Association between circulating tumor DNA and Pseudoprogression in patients with metastatic melanoma treated with anti-programmed cell death 1 antibodies. JAMA Oncol. 2018;4(5):717-21. https://doi.org/10.1001/ja maoncol.2017.5332.

\section{Publisher's Note}

Springer Nature remains neutral with regard to jurisdictional claims in published maps and institutional affiliations.

Ready to submit your research? Choose BMC and benefit from:

- fast, convenient online submission

- thorough peer review by experienced researchers in your field

- rapid publication on acceptance

- support for research data, including large and complex data types

- gold Open Access which fosters wider collaboration and increased citations

- maximum visibility for your research: over $100 \mathrm{M}$ website views per year

At BMC, research is always in progress.

Learn more biomedcentral.com/submissions 